\title{
Verteporfin Photodynamic Therapy \\ for the Treatment of Choroidal Conditions-An Overview
}

\author{
Jaycob Avaylon and Ron P Gallemore \\ Retina Macula Institute, Torrance, CA, USA
}

DOl: https://doi.org/10.17925/USOR.2019.12.2.69

\section{Keywords}

AMD, central serous chorioretinopathy, choroidal neovascularization, circumscribed choroidal hemangioma, polypoidal choroidal vasculopathy, verteporfin photodynamic therapy, vPDT

Disclosure: Jaycob Avaylon and Ron P Gallemore have nothing to declare in relation to this article.

Acknowledgments: Editorial assistance was provided by Stuart Wakelin of Touch Medical Communications and funded by Bausch Health US, LLC.

Review Process: Double-blind peer review.

Compliance with Ethics: This study involves a review of the literature and did not involve any studies with human or animal subjects performed by either of the authors.

Authorship: The named authors meet the International Committee of Medical Journal Editors (ICMJE) criteria for authorship of this manuscript, take responsibility for the integrity of the work as a whole, and have given final approval for the version to be published.

Received: July 25, 2019

Accepted: November 13, 2019

Citation: US Ophthalmic Review, 2019;12(2):69-78

Corresponding Author: Ron P. Gallemore, Retina Macula Institute, 4201 Torrance Blvd, Suite 220, Torrance, CA 90503, USA. E: rongallemoremd@gmail.com

Support: The publication of this article was supported by Bausch Health US, LLC. The views and opinions expressed are those of the authors.
Photodynamic therapy (PDT) is a technique involving the use of a photosensitizing agent that, when activated by light of a specific wavelength, causes localized and selective tissue damage. ${ }^{1,2}$ Initially developed to treat tumor cells using tumor-localizing photosensitizing agents (e.g., Photofrin ${ }^{\circledR}$, Pinnacle Biologics, Chicago, IL USA), ${ }^{1}$ ophthalmic PDT was developed in the 1990 s to treat conditions such as choroidal neovascularization (CNV) associated with age-related macular degeneration (AMD). ${ }^{2}$ While several ophthalmic sensitizing agents were initially developed, verteporfin was shown to have the most promising overall efficacy, safety, and chemical characteristics (e.g., a longer absorption spectrum, thereby enabling activation further into the tissue, a lipophilic nature to support localization, and a short half-life to minimize the duration of skin photosensitivity). ${ }^{2-4}$ Here we review the mechanism of action, current applications, and supporting evidence for the use of verteporfin PDT (VPDT) in the treatment of various choroidal conditions, including CNV associated with AMD, central serous chorioretinopathy (CSC), polypoidal choroidal vasculopathy (PCV), choroidal hemangioma, and peripapillary CNV.

\section{Verteporfin photodynamic therapy mechanism of action and standardized protocol}

Verteporfin is transported in the plasma, primarily by low density lipoproteins, and was developed to preferentially accumulate in abnormal neovascular endothelial cells, due to an increased expression of low density lipoproteins receptors compared with normal choroidal and retinal vessels. ${ }^{25,6}$ Once photoactivated, verteporfin generates highly reactive, short-lived singlet oxygen and reactive oxygen radicals, causing selective and local damage to neovascular endothelium and choroidal vascular occlusion. ${ }^{2.5}$ This selective occlusion of choroidal neovasculature by VPDT causes minimal damage to the neurosensory retina and, therefore, does not induce loss of visual acuity (VA). ${ }^{7}$ This allows VPDT to be used in the large proportion of patients not eligible for more destructive procedures such as photocoagulation. ${ }^{7}$

The 'standard' VPDT protocol is a two-step procedure developed for use in patients with subfoveal CNV associated with AMD, and first used in the TAP (Treatment of Age-related macular degeneration with photodynamic Therapy) and VIP (Verteporfin In Photodynamic therapy) studies (Table 1). ${ }^{8-10}$ The procedure involves two main steps: (i) intravenous administration of verteporfin at a dose of $6 \mathrm{mg} / \mathrm{m}^{2}$ over 10 minutes at a rate of $3 \mathrm{~mL} / \mathrm{min}$, followed by a 5 -minute wait, 5,11 and (ii) photoactivation of the verteporfin using laser light of $689 \mathrm{~nm}$ at a recommended light dose of $50 \mathrm{~J} / \mathrm{cm}^{2}$ per neovascular lesion at an intensity of $600 \mathrm{~mW} / \mathrm{cm}^{2}$ over 83 seconds. ${ }^{5.11}$ The use of $689 \mathrm{~nm}$ red light ensures good penetration through melanin, blood, and fibrotic tissue and effective treatment of the choroidal 
Table 1: Summary of key clinical trials involving (or relating to) VPDT for the treatment of CNV associated with AMD and peripapillary CNV

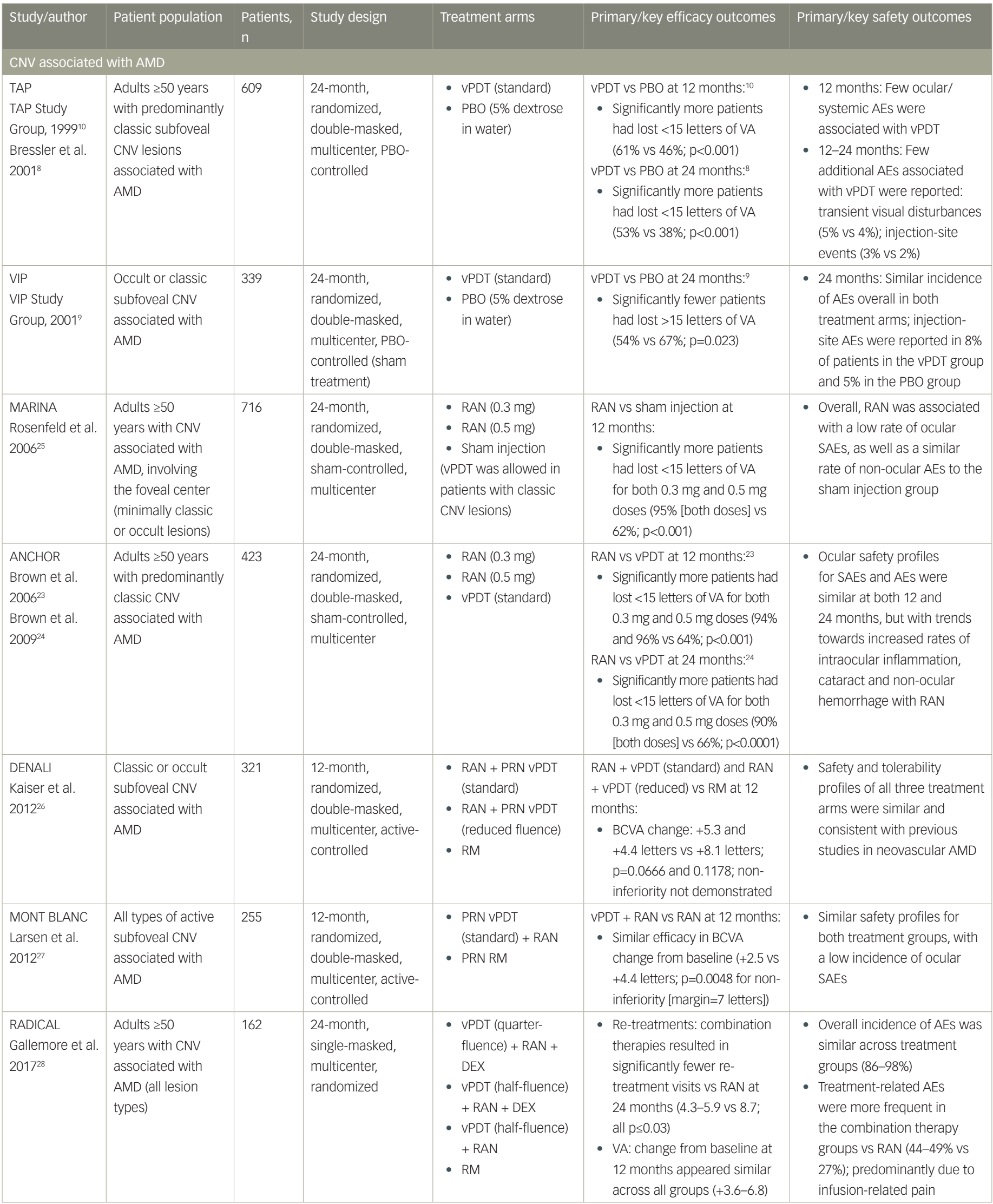


Table 1: Cont.

\begin{tabular}{|c|c|c|c|c|c|c|}
\hline Study/author & Patient population & $\begin{array}{l}\text { Patients, } \\
\mathrm{n}\end{array}$ & Study design & Treatment arms & $\begin{array}{l}\text { Primary/key efficacy } \\
\text { outcomes }\end{array}$ & $\begin{array}{l}\text { Primary/key safety } \\
\text { outcomes }\end{array}$ \\
\hline \multicolumn{7}{|c|}{ Peripapillary CNV } \\
\hline $\begin{array}{l}\text { Rosenblatt } \\
\text { et al. } 2005^{67}\end{array}$ & $\begin{array}{l}\text { Symptomatic } \\
\text { extrafoveal } \\
\text { peripapillary CNV }\end{array}$ & 7 & $\begin{array}{l}\text { Interventional case } \\
\text { series }\end{array}$ & $\begin{array}{l}\text { - } \text { VPDT (reduced } \\
\text { fluence; } 18 \mathrm{~J} / \mathrm{cm}^{2} \text { ) }\end{array}$ & $\begin{array}{l}\text { - In 6/7 eyes (86\%), a VA } \\
\text { improvement of at least } \\
2 \text { Snellen lines was observed }\end{array}$ & $\begin{array}{l}\text { - No complications (including } \\
\text { optic neuropathy) in any } \\
\text { treated eyes }\end{array}$ \\
\hline $\begin{array}{l}\text { Bernstein et al. } \\
2008^{68}\end{array}$ & $\begin{array}{l}\text { Peripapillary CNV } \\
\text { second to AMD }\end{array}$ & 7 & $\begin{array}{l}\text { Retrospective, } \\
\text { interventional case } \\
\text { series }\end{array}$ & - VPDT (standard) & $\begin{array}{l}\text { - All patients showed improved } \\
\text { VA with resolution of } \\
\text { peripapillary hemorrhage }\end{array}$ & $\begin{array}{l}\text { - No evidence of optic } \\
\text { nerve damage, despite the } \\
\text { treatment zone overlapping } \\
\text { the optic nerve in all cases }\end{array}$ \\
\hline
\end{tabular}

$A E S=$ adverse events; $A M D=$ age-related macular degeneration; $A N C H O R=$ anti-VEGF antibody for the treatment of predominantly classic choroidal neovascularization in $A M D$; $B C V A$ = best-corrected visual acuity; $C N V$ = choroidal neovascularization; DENALI = verteporfin plus ranibizumab for choroidal neovascularization in $A M D ; D E X=$ dexamethasone $(0.5 \mathrm{mg}) ;$ MARINA = minimally classic/occult trial of the anti-VEGF antibody ranibizumab in the treatment of neovascular AMD; MONT BLANC = verteporfin photodynamic therapy administered in conjunction with ranibizumab in patients with subfoveal choroidal neovascularization secondary to $A M D: P B O=$ placebo: $P R N=$ pro re nata (as required): RADICAL = reduced fluence Visudyne-anti-VEGF-dexamethasone in combination for AMD lesions; $R A N=$ ranibizumab (0.5 mg [unless otherwise stated]); RM = ranibizumab monotherapy; $S A E=$ serious adverse event; TAP = treatment of age-related macular degeneration with photodynamic therapy; VA = visual acuity; VIP = verteporfin in photodynamic therapy; $V P D T=$ verteporfin photodynamic therapy.

vasculature. ${ }^{2}$ The vPDT laser delivery system also produces a circular spot of light, which is adjusted to exceed the greatest linear dimension of the target lesion, usually up to a maximum of 7,000 $\mu \mathrm{m}^{2}{ }^{2}$

While the standard VPDT protocol was shown to have a favorable safety profile in the TAP and VIP studies, ${ }^{8-10}$ as the photochemical reaction has a dose-dependent response, different protocols have since been developed to enhance the efficacy and/or safety of VPDT, usually by adjusting either the verteporfin dose administered (e.g. $3 \mathrm{mg} / \mathrm{m}^{2}$ ) or the laser fluence (e.g. $\left.25 \mathrm{~J} / \mathrm{cm}^{2}\right) .{ }^{2}$ As a result of this adaptability, VPDT has potential applications across a range of chorioretinal conditions, which will be discussed here.

Several reviews published approximately a decade ago, indicated, at the time, that VPDT was the treatment of choice for common and, some less common, choroidal neovascular conditions. ${ }^{12-15}$ This was supported by numerous clinical studies that provided high-quality evidence. Since that time, the emergence of the anti-vascular endothelial growth factor (VEGF) agents, particularly ranibizumab, aflibercept, and bevacizumab, has changed the treatment landscape and these have now become the standard therapies. ${ }^{16}$ Nevertheless, VPDT remains a valuable treatment; some current recommendations state that poor or non-response to anti-VEGF treatments requires re-evaluation of diagnosis and, if necessary, a switch to alternative therapies including other anti-VEGF agents and/or VPDT. ${ }^{17}$

\section{Choroidal neovascularization}

AMD is a progressive maculopathy that typically occurs in patients $>50$ years and has two distinct classifications: 'dry' AMD, characterized by non-neovascular pathology with drusen or abnormalities of the retinal pigment epithelium (RPE); and 'wet' (neovascular) AMD, characterized by CNV. ${ }^{18,19}$ With the latter, neovascular proliferation from the choriocapillaris extends under the Bruch's membrane and invades the space under the RPE, causing the leakage of serous fluid. ${ }^{18,20}$ This is associated with the development of fibrous tissues that replace the normal architecture of the outer retina, and often leads to RPE detachment and atrophy, hemorrhages, scarring, and severe and irreversible loss of central vision. ${ }^{18,19}$ Although neovascular $A M D$ is less prevalent than dry AMD, with approximately 500,000 new cases of neovascular AMD occurring each year, it accounts for $\sim 90 \%$ of all AMD cases that result in vision loss and it has been estimated that approximately 8 million older-age adults are at high risk of developing AMD in the US alone. ${ }^{18,21}$ AMD risk can be reduced by diet; the largescale Age Related Eye Disease study (AREDS) reported that a nutritional supplement known as the AREDS formulation, which contained vitamin $C$, vitamin $E$, beta-carotene, zinc and copper, reduced the risk of AMD progression.22 However, beta carotene was associated with an increased risk of lung cancer in smokers. The subsequent AREDS2 reported that lutein and zeaxanthin could be used as a safe and effective alternative to beta carotene, but the addition of omega- 3 fatty acids did not provide a statistically significant benefit in study participants. ${ }^{22}$ The ideal treatment for neovascular AMD would involve the destruction of the choroidal neovasculature while preserving the overlying retina. ${ }^{18}$ As such, VPDT provides a viable therapeutic approach to the treatment of this condition.

Following promising results in early phase I and phase II clinical trials of single VPDT treatments in $\mathrm{CNV}^{3}{ }^{3}$ multiple VPDT treatment strategies were

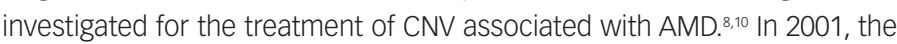
TAP study investigated the effectiveness of VPDT therapy in the treatment of predominantly classic CNV lesions in patients with AMD., ${ }^{8,10}$ At both 12 and 24 months following VPDT treatment, significantly more patients in the VPDT group had lost fewer than 15 letters ( 3 lines) of VA compared with the placebo group (both $p<0.001$; Table 1). ${ }^{8,10}$ At 12 months, few ocular/systemic adverse events were associated with verteporfin treatment, compared with placebo (PDT with 5\% dextrose in water), including transient visual disturbances (18\% versus 12\%), injection-site adverse events (13\% versus $3 \%$ ), transient photosensitivity reactions (3\% versus $0 \%$ ), and infusionrelated low back pain (2\% versus $0 \%) .{ }^{10}$ Few additional photosensitivity adverse reactions and injection site adverse events were associated with VPDT in the second year of follow-up (Table 1). ${ }^{8}$

However, in 2006, results from the MARINA and ANCHOR studies demonstrated the effectiveness of anti-VEGF therapy (ranibizumab) for the treatment of all types of CNV lesions in AMD, not only compared with placebo (sham injections), but also compared with VPDT therapy (Table 1).23-25 In both these studies ranibizumab was shown to stabilize VA for up to 2 years in the large majority of patients ( $\geq 90 \%$ ), and even improve VA in $~ 30 \%$ of patients, with a favorable safety profile. ${ }^{23-25}$ Anti-VEGF therapy subsequently became the modality of choice for the treatment of neovascular AMD. 
Since then, several studies have investigated the potential benefits of anti-VEGF and VPDT dual combination therapy (DENALI and MONT BLANC studies) ${ }^{26,27}$ and anti-VEGF, VPDT and dexamethasone triple therapy (RADICAL study), ${ }^{28}$ for the treatment of CNV associated with AMD (Table 1). In the DENALI study, although the non-inferiority (defined as a best-corrected visual acuity [BCVA] margin of $\leq 7$ letters) of combined VPDT + ranibizumab regimens (standard or reduced fluence VPDT + $0.5 \mathrm{mg}$ ) to ranibizumab monotherapy $(0.5 \mathrm{mg})$ was not demonstrated at 1 year, fewer ranibizumab re-treatments were required with VPDT combination therapy (5.1 and 5.7 versus 10.5 injections, with standard and reduced VPDT versus ranibizumab monotherapy, respectively). ${ }^{26}$ In contrast, the MONT BLANC study did demonstrate the non-inferiority (again, defined as a BCVA margin of $\leq 7$ letters) of VPDT + ranibizumab combination therapy compared with ranibizumab monotherapy at 1 year, but with no significant benefit to the number of ranibizumab re-treatments. ${ }^{27}$

The RADICAL study also showed significantly fewer re-treatment visits with triple combination therapy (VPDT + ranibizumab + dexamethasone) compared with ranibizumab monotherapy for up to 2 years, with similar apparent improvements in VA between the treatment groups. ${ }^{28}$ Studies of VPDT in nonAMD-associated CNV present similar findings to those in neovascular AMD, with anti-VEGF therapy providing better visual outcomes (though requiring more re-treatments) than VPDT in myopic CNV for up to 1 year (RADIANCE study), ${ }^{29}$ better visual outcomes than VPDT for up to 2 years in idiopathic CNV, and clinical benefits in other causes of CNV including pathologic myopia, ocular histoplasmosis, and angioid streaks. ${ }^{31}$ Nevertheless, vPDT remains an important treatment in the chorioretinal armamentarium, not only as alternative therapy in patients with AMD-associated CNV who do not respond to anti-VEGF therapy (or are unable to tolerate the intravitreal injections), ${ }^{32}$ but potentially in alternative choroidal conditions with similar pathologies, such as CSC, CSC with CNV, PCV, choroidal hemangioma, and peripapillary CNV. It should be noted, that although VPDT is important in PVC and CSC, it has become less important and less used in the treatment of wet AMD.

\section{Central serous chorioretinopathy}

CSC is a disorder characterized by serous retinal detachment and/or RPE detachment, changes most often confined to the macula, and is associated with leakage of fluid through the RPE into the subretinal space. ${ }^{33}$ It is broadly classified into two categories: acute CSC, which tends to affect younger patients and generally resolves spontaneously within 1-4 months; and chronic or recurrent CSC, which involves frequent recurrences or chronic retinal detachment that can lead to RPE atrophy and permanent loss of visual function. ${ }^{33}$ Overall, CSC typically affects men (male:female ratio of 2.7:1 to 7:1) with an average age of 45-51 years, 33,34 and while the exact etiology of CSC is still not completely understood, it is believed to involve thickening of the choroid, choroidal vasculopathy and RPE defects that result in the characteristic leakage of fluid through the RPE. ${ }^{33}$ Further, CNV can be secondary to CSC, with a similar presentation to neovascular AMD associated $C N V$, and potentially result in severe vision loss. ${ }^{33}$ As such, the proposed mechanism for treatment of chronic CSC is closure of the abnormal leaking choroidal vessels, allowing subsequent vascular remodeling of the choroid. ${ }^{2}$ While laser photocoagulation is one method for achieving this, it has been associated with significant adverse events such as symptomatic scotomas, RPE atrophy and secondary CNV. ${ }^{2}$

As an alternative to laser photocoagulation, vPDT has demonstrated efficacy not only in promoting the resolution of acute CSC (i.e., enabling reabsorption of subretinal fluid and improving VA), but also preventing recurrences and benefitting patients with chronic disease. ${ }^{33}$ There are a large number of published studies on the use of VPDT to treat both acute and chronic CSC, and while most of these are interventional case series, ${ }^{35}$ there have also been several randomized controlled trials using adapted 'standard' VPDT protocols to improve safety outcomes (Table 2). ${ }^{36-43}$ For the treatment of acute CSC, these include a randomized, double-masked, controlled clinical trial by Chan et al. investigating half-dose VPDT therapy ( $3 \mathrm{mg} / \mathrm{m}^{2}$, fluence $50 \mathrm{~J} / \mathrm{cm}^{2}$ ) in 63 patients with subretinal fluid for $<3$ months; Table 2). ${ }^{36} \mathrm{In}$ this study, significantly more patients who received VPDT therapy had no subretinal fluid visible using OCT after 1 year compared with placebo (30 $\mathrm{mL}$ saline solution; $94.9 \%$ versus $57.9 \% ; \mathrm{p}=0.001$ ), and significantly more patients had stable or improved VA in the VPDT group compared with placebo (100.0\% versus 78.9\%; $p=0.009)$. ${ }^{36}$ No ocular or systemic adverse events were reported.

For the treatment of chronic $\mathrm{CSC}$, these include a randomized trial conducted by Bae et al. in 32 patients who had subretinal fluid for $>6$ months, which compared VPDT (fluence: $25 \mathrm{~J} / \mathrm{cm}^{2}$; light dose $300 \mathrm{~mW} / \mathrm{cm}^{2}$ ) and ranibizumab (three injections of $0.5 \mathrm{mg}$; Table 2) ${ }^{37}$ At 12 months, significantly more eyes in the VPDT group compared with the ranibizumab group maintained complete resolution of subretinal fluid with rescue medication (88.9\% versus 12.5\%; p<0.001). ${ }^{37}$ Adverse events were reported only in the ranibizumab group (three eyes; all events secondary to intravitreal injections) and there were no serious adverse events. ${ }^{37}$ For patients with chronic CSC recalcitrant to conventional therapy (including anti-VEGF monotherapy), a retrospective analysis by Asahi et al. showed that combination therapy with VPDT + anti-VEGF therapy led to complete resolution of subretinal fluid in all patients (100\%), with a significant reduction in mean central macular thickness after 4 months $(401 \mu \mathrm{m}$ to $298 \mu \mathrm{m} ; \mathrm{p}=0.001){ }^{38}$ In these cases, it was thought that the efficacy observed may be due, in part, to VPDT-sensitive lesions associated with underlying $\mathrm{CNV}$, something which has been reported in cases of chronic $\mathrm{CSC}^{38}$ In addition, combining anti-VEGF VPDT can have an additive effect on the resolution of chronic CSC by further stimulation of fluid absorption, and may serve as prophylaxis against iatrogenic CNV, as well as treatment of any underlying occult CNV. Overall, the authors concluded that associated CNV and/or inflammation may be the reason for greater success in CSC patients treated with combination therapy. ${ }^{38}$

In addition, Ma et al. conducted a meta-analysis of nine randomized controlled trials (319 eyes) and observational studies comparing VPDT with both laser photocoagulation therapy and anti-VEGF therapy. ${ }^{44}$ Results of this meta-analysis showed that half dose VPDT ( $3 \mathrm{mg} / \mathrm{m}^{2}$ ) significantly improved the resolution of subretinal fluid versus laser photocoagulation ( $p=0.005)$, and that VPDT significantly improved the resolution of subretinal fluid and decreased central macular thickness versus anti-VEGF therapy ( $p=0.007$ and $p=0.002$, respectively) ${ }^{44} A$ further meta-analysis of three studies found that eyes of patients who received VPDT showed better BCVA and central macular thickness than those who received placebo for 12 months. ${ }^{45}$ A meta-analysis of a further two studies showed that BCVA at the first month after injection was better for anti-VEGF than for placebo but not at 3 and 6 months after injection. ${ }^{45}$ This analysis found no direct comparisons of VPDT with anti-VEGF for acute CSC. No severe complications were reported in the included studies. The analysis concluded that current evidence suggested that early treatment of acute CSC by VPDT is valuable in improving $V A$, reducing subretinal fluid, and maintaining long term effectiveness. It 
Table 2: Summary of key clinical trials involving VPDT for the treatment of CSC

\begin{tabular}{|c|c|c|c|c|c|c|}
\hline Study/author & $\begin{array}{l}\text { Patient } \\
\text { population }\end{array}$ & $\mathrm{n}$ & Study design & Treatment arms & Primary/key efficacy outcomes & $\begin{array}{l}\text { Primary/key safety } \\
\text { outcomes }\end{array}$ \\
\hline $\begin{array}{l}\text { Chan et al. } \\
2008^{36}\end{array}$ & Acute CSC & 63 & $\begin{array}{l}\text { 12-month, } \\
\text { prospective, } \\
\text { double-masked, } \\
\text { placebo-controlled, } \\
\text { randomized }\end{array}$ & $\begin{array}{l}\text { - } \operatorname{vPDT} \text { (half-dose; } \\
\left.3 \mathrm{mg} / \mathrm{m}^{2}\right) \\
\text { - } \mathrm{PBO}(30 \mathrm{~mL} \text { saline } \\
\text { solution) }\end{array}$ & $\begin{array}{l}\text { VPDT vs PBO at } 12 \text { months } \\
\text { - } \text { Absence of subretinal fluid: } 95 \% \text { vs } \\
58 \% \text { ( } p=0.001) \\
\text { - LogMAR BCVA: }-0.05 \text { vs } 0.05 \text { ( } p=0.008)\end{array}$ & $\begin{array}{l}\text { - No ocular or systemic } \\
\text { AEs were reported }\end{array}$ \\
\hline $\begin{array}{l}\text { Wu et al. } \\
2011^{40}\end{array}$ & Acute CSC & 34 & $\begin{array}{l}\text { 12-month, } \\
\text { randomized }\end{array}$ & $\begin{array}{l}\text { - vPDT (half-dose; } 3 \text { mg/ } \\
\text { m²) }^{\text {- }} \text { PBO ( } 30 \mathrm{~mL} \text { saline } \\
\text { solution) }\end{array}$ & $\begin{array}{l}\text { VPDT vs PBO at } 12 \text { months } \\
\text { - VA improvement: } 1.8 \text { vs } 0.1 \text { lines } \\
\text { ( } p=0.003) \\
\text { - Lower central foveal thickness with } \\
\text { VPDT ( } p=0.028)\end{array}$ & $\begin{array}{l}\text { - No systemic AEs were } \\
\text { reported } \\
\text { - } \text { At } 12 \text { months, ocular } \\
\text { AEs included atrophy in } \\
\text { the treatment area (2\%) } \\
\text { and juxtafoveal CNV (2\%) }\end{array}$ \\
\hline $\begin{array}{l}\text { Reibaldi et al. } \\
2010^{39}\end{array}$ & Chronic CSC & 42 & $\begin{array}{l}\text { 12-month, } \\
\text { prospective, } \\
\text { investigator- } \\
\text { masked, non- } \\
\text { randomized }\end{array}$ & $\begin{array}{l}\text { - ICGA-guided vPDT } \\
\text { (standard fluence; } 50 \\
\mathrm{~J} / \mathrm{cm}^{2} \text { ) } \\
\text { - } \text { ICGA-guided VPDT } \\
\text { (half-fluence; } 25 \mathrm{~J} / \mathrm{cm}^{2} \text { ) }\end{array}$ & $\begin{array}{l}\text { - Both groups significantly improved } \\
\text { LogMAR BCVA vs baseline ( } p<0.01 \text { ) } \\
\text { Standard vs half fluence at } 12 \text { months } \\
\text { - Complete subretinal reabsorption in } \\
79 \% \text { vs } 91 \% \text { of patients ( } p=0.5 \text { ) } \\
\text { - Choriocapillaris non-perfusion in } 44 \% \\
\text { vs } 0 \% \text { of patients ( } p=0.002 \text { ) }\end{array}$ & Not reported \\
\hline $\begin{array}{l}\text { Semeraro et al. } \\
2012^{41}\end{array}$ & $\begin{array}{l}\text { Chronic CSC } \\
\text { ( } \geq 3 \text { months) }\end{array}$ & 22 & $\begin{array}{l}\text { 9-month, } \\
\text { prospective, } \\
\text { comparative, } \\
\text { interventional }\end{array}$ & $\begin{array}{l}\text { - VPDT (half fluence: } 25 \\
\mathrm{~J} / \mathrm{cm}^{2}, 300 \mathrm{~mW} / \mathrm{cm}^{2} \text { ) } \\
\text { - Bevacizumab } \\
\text { (1.25 mg) }\end{array}$ & $\begin{array}{l}\text { VPDT vs bevacizumab at } 9 \text { months } \\
\text { - VA: improvements vs baseline in } \\
\text { both groups ( } p \leq 0.032) \text {; no significant } \\
\text { difference between groups ( } p=0.59 \text { ) }\end{array}$ & $\begin{array}{l}\text { - No AEs were reported } \\
\text { in either group for up to } \\
1 \text { year of follow-up }\end{array}$ \\
\hline $\begin{array}{l}\text { Bae et al. } \\
2014^{37}\end{array}$ & $\begin{array}{l}\text { Chronic CSC } \\
\text { (>6 months) }\end{array}$ & 32 & $\begin{array}{l}\text { 12-month, } \\
\text { prospective, } \\
\text { randomized, single- } \\
\text { center, parallel-arm, } \\
\text { active-controlled }\end{array}$ & $\begin{array}{l}\text { - } \text { VPDT (half } \\
\text { fluence: } 25 \mathrm{~J} / \mathrm{cm}^{2} \text {, } \\
\left.300 \mathrm{~mW} / \mathrm{cm}^{2}\right) \\
\text { - RAN (3 x } 0.5 \mathrm{mg})\end{array}$ & $\begin{array}{l}\text { VPDT vS RAN at } 12 \text { months } \\
\text { - Complete resolution of subretinal } \\
\text { fluid with rescue medication: } 88.9 \% \text { vs } \\
12.5 \%(p<0.001)\end{array}$ & $\begin{array}{l}\text { - No serious treatment- or } \\
\text { procedure-related AES } \\
\text { reported } \\
\text { - } \text { AES only reported in the } \\
\text { RAN group (injection- } \\
\text { related) }\end{array}$ \\
\hline $\begin{array}{l}\text { Russo et al. } \\
2017^{42}\end{array}$ & Chronic CSC & 40 & $\begin{array}{l}\text { 6-month, } \\
\text { prospective, } \\
\text { randomized, } \\
\text { open-label, active- } \\
\text { controlled }\end{array}$ & $\begin{array}{l}\text { - vPDT (half-dose; } \\
\left.3 \mathrm{mg} / \mathrm{m}^{2}\right) \\
\text { - Laser therapy } \\
\left(689 \mathrm{~nm} ; 95 \mathrm{~J} / \mathrm{cm}^{2} \text {, }\right. \\
\left.805 \mathrm{~mW} / \mathrm{cm}^{2}, 118 \mathrm{~s}\right)\end{array}$ & $\begin{array}{l}\text { - Both groups showed significant } \\
\text { improvements in BCVA, central retinal } \\
\text { thickness and subfoveal choroid } \\
\text { thickness } \\
\text { - Resolution of central retinal thickness } \\
\text { occurred faster with VPDT therapy vs } \\
\text { laser therapy. There were no other } \\
\text { significant differences between } \\
\text { groups }\end{array}$ & $\begin{array}{l}\text { - No ocular or systemic } \\
\text { AEs associated with } \\
\text { treatment were reported }\end{array}$ \\
\hline $\begin{array}{l}\text { Cheng et al. } \\
2017^{43}\end{array}$ & Chronic CSC & 40 & $\begin{array}{l}\text { 6-month, } \\
\text { randomized, } \\
\text { observer-masked }\end{array}$ & $\begin{array}{l}\text { - vPDT (half-dose; } 3 \mathrm{mg} / \\
\mathrm{m}^{2} \text { ) } \\
\text { - } \mathrm{vPDT} \text { (half fluence; } 25 \\
\mathrm{~J} / \mathrm{cm}^{2}, 43 \mathrm{~s} \text { ) }\end{array}$ & $\begin{array}{l}\text { - VA and central retinal thickness were } \\
\text { significantly improved ( } p<0.01 \text { vs } \\
\text { baseline) at } 6 \text { months in both groups; } \\
\text { there was no significant difference } \\
\text { between groups } \\
\text { - All but one patient (half-fluence } \\
\text { group) had complete absorption of } \\
\text { subretinal fluid at } 6 \text { months }\end{array}$ & $\begin{array}{l}\text { - No ocular or systemic } \\
\text { complications were } \\
\text { observed in any patients } \\
\text { in either treatment } \\
\text { group }\end{array}$ \\
\hline $\begin{array}{l}\text { Asahi et al. } \\
2017^{38}\end{array}$ & $\begin{array}{l}\text { Chronic CSC } \\
\text { recalcitrant to } \\
\text { conventional } \\
\text { therapy (including } \\
\text { anti-VEGF) }\end{array}$ & 8 & $\begin{array}{l}\text { 4-month, } \\
\text { retrospective, case } \\
\text { series }\end{array}$ & $\begin{array}{l}\text { - vPDT (half fluence; } \\
25 \mathrm{~J} / \mathrm{cm}^{2}, 300 \mathrm{~mW} / \\
\left.\mathrm{cm}^{2}\right)+ \text { anti-VEGF } \\
\text { (bevacizumab or } \\
\text { aflibercept) }\end{array}$ & $\begin{array}{l}\text { - All patients ( } 100 \%) \text { achieved complete } \\
\text { resolution of subretinal fluid } \\
\text { - Mean central macular thickness was } \\
\text { significantly reduced at } 4 \text { months } \\
(401 \mu \mathrm{m} \text { to } 298 \mu \mathrm{m} ; \mathrm{p}=0.001)\end{array}$ & $\begin{array}{l}\text { - No systemic or infusion } \\
\text { AEs were reported, } \\
\text { including visual loss }\end{array}$ \\
\hline
\end{tabular}

$A E=$ adverse event; $B C V A=$ best-corrected visual acuity; $C S C=$ central serous chorioretinopathy; $I C G A=$ indocyanine green angiography; $P B O=$ placebo; $R A N=$ ranibizumab; $V E G F=$ vascular endothelial growth factor; VPDT = verteporfin photodynamic therapy.

was also concluded that anti-VEGF injection could shorten the duration of symptoms and accelerate visual improvement at early stage of disease. ${ }^{45}$ This analysis and another review concluded that a direct comparison between these two treatments is needed to fully evaluate their relative efficacy. ${ }^{45,46}$ While not currently indicated for the treatment of CSC, VPDT has been extensively studied in this condition, is considered the current 
standard of care alongside focal laser therapy, and was granted orphan drug designation for the potential treatment of chronic and recurrent CSC by the US Food and Drug Administration (FDA) in 2012. ${ }^{47}$

\section{Polypoidal choroidal vasculopathy}

PCV is an exudative maculopathy characterized by an inner choroidal branching vascular network with polypoidal lesions. ${ }^{2}$ Typically, the condition manifests as recurrent episodes of serous and/or hemorrhagic RPE and retinal detachment, and if left untreated, the long-term visual prognosis is poor. ${ }^{2,48}$ While it is established that PCV is prevalent in Asian individuals, occurring in 22.3-61.6\% of patients with neovascular AMD, ${ }^{48}$ it occurs across all racial/ethnic groups and there is evidence that it may be more prevalent in other ethnic populations than previously thought, with the increased use of indocyanine green angiography and other diagnostic techniques showing a rise in the frequency of PCV diagnoses across all patient populations. ${ }^{48}$ Although the etiology of PCV is not fully understood, it is believed to be due to atherosclerosis of the choroidal vessels. ${ }^{2}$ As such, the optimal approach to treatment of PCV remains uncertain, though histopathological evidence suggests that PCV may be a variant of the CNV seen in neovascular AMD, indicating that a similar therapeutic approach may be viable. ${ }^{48}$ Indeed, PCV can often be misdiagnosed as CNV, as it can mimic CNV on fundus photography and fluorescence fundus angiography. ${ }^{49}$ Because the role of VEGF in the pathogenesis of PCV is believed to be substantially less important than in $\mathrm{CNV}^{49}$ it is possible that many cases of anti-VEGF-treatment-resistant AMD may have a driving PCV pathology, and alternative treatment methods, such as VPDT, may be indicated.

Several randomized clinical trials have demonstrated the efficacy of VPDT (with or without anti-VEGF therapy) for improving visual outcomes and achieving polyp regression in patients with PCV (Table 3). ${ }^{48,50-54}$ These include EVEREST, a 6-month, randomized study investigating the use of VPDT (standard) + ranibizumab ( $3 \times 0.5 \mathrm{mg}$ ) combination therapy versus VPDT or ranibizumab monotherapy in Asian patients with symptomatic $\mathrm{PCV}^{50}$ and the 24-month, similarly-designed, follow-up study: EVEREST II. The EVEREST study $(n=61)$ showed that both VPDT + ranibizumab and VPDT monotherapy were superior to ranibizumab monotherapy in achieving complete polyp regression at 6 months (77.8\% and $71.4 \%$ versus $28.6 \% ; p<0.01$; Table 3). This improved efficacy was not associated with any new safety findings. More recently, 1-year results from the 2-year, multicenter, randomized, double-masked, EVEREST II study ( $n=322$ ) have been made available. These showed that in Asian patients with PCV, VPDT + ranibizumab $(3 \times 0.5 \mathrm{mg})$ provided significant improvements in VA versus ranibizumab alone (mean difference at 1 year: 3.2 letters, 95\% confidence interval [Cl]: 0.4-6.1), meeting both non-inferiority and superiority criteria ( $\mathrm{p}=0.01$; Table 3 ). ${ }^{48}$ In addition, combination therapy was also superior to ranibizumab monotherapy in achieving complete polyp regression (69.3\% versus $34.7 \%$ at 1 year; $p<0.001)$. The incidence of ocular adverse events was similar between treatment groups (26.7\% versus $25.5 \%$ ), with vitreous hemorrhage the only ocular serious adverse event reported (vPDT + ranibizumab: 1 [0.6\%]; ranibizumab monotherapy: 3 [2.0\%]). ${ }^{48}$

In addition to randomized clinical trials, Wong et al. conducted a systematic review of the literature for studies investigating the use of VPDT both with and without anti-VEGF therapy for the treatment of PCV. ${ }^{55}$ Overall, a pooled analysis of 29 studies (316 eyes reporting 3-year visual outcomes) showed significant improvements in VA at both 1 and 2 years post-treatment with VPDT + ranibizumab versus VPDT monotherapy. ${ }^{55}$ These findings at 1 and 2 years post-treatment were supported by a separate systematic literature review and meta-analysis conducted by Wang et al., who showed that combination therapy with VPDT + anti-VEGF provided significantly improved VA at 1 and 2 years compared with VPDT monotherapy in patients with PCV $\left(p=0.028\right.$ and $p=0.008$, respectively) ${ }^{56}$

Similar to the situation with CSC, while VPDT is not currently indicated for the treatment of PCV, the numerous studies supporting the effectiveness of treatments, taken together with the results of the recent EVEREST-II study, suggest that combination therapy with VPDT + anti-VEGF may be the optimal treatment for patients with PCV, reflected in their inclusion in evidence-based treatment guidelines. ${ }^{57}$

The benefit of VPDT rescue therapy in PCV was also evaluated in the PLANET study (Table 3). ${ }^{54} \mathrm{~A}$ total of 318 patients with PCV (mean age 70.6 years) were randomized $1: 1$ to receive $2 \mathrm{mg}$ of aflibercept at weeks 0,4 , and 8 . At week 12, patients with a suboptimal response were randomized 1:1 to receive aflibercept + sham VPDT or a "rescue" of aflibercept plus VPDT. The results showed that aflibercept monotherapy was noninferior to aflibercept + VPDT for BCVA (+10.7 versus +10.8 letters, respectively; 95\% $\mathrm{Cl},-2.9$ to $1.6 ; \mathrm{p}=0.55)$. However, fewer than $17 \%$ of patients met the criteria of a suboptimal response to receive rescue VPDT so the potential benefit of adding PDT could not be determined..$^{54,58}$

\section{Circumscribed choroidal hemangioma}

Choroidal hemangiomas are benign vascular hematomas that are usually circumscribed, but can also be diffuse (e.g., with Sturge-Webber syndrome), ${ }^{59}$ and typically only require treatment when vision is affected by macular edema or exudative retinal detachment. ${ }^{2}$ Various treatments have been previously used to treat choroidal hemangiomas (e.g., laser photocoagulation, radiation therapy). ${ }^{2.59}$ However, as VPDT was initially developed to treat tumors via selective destruction of the tumor or tumor vasculature, it provides a clear alternative therapeutic option. ${ }^{2}$

There have been many case reports and case series demonstrating the use of VPDT to effectively treat choroidal hemangiomas with minimal complications, ${ }^{2,60,61}$ but only one controlled, comparative case series: a prospective, randomized, interventional study by Pilotto et al. (Table 4). ${ }^{62}$ In this study, 20 consecutive cases of choroidal hemangioma were randomized to receive VPDT (standard) or bolus VPDT (a $6 \mathrm{mg} / \mathrm{m}^{2}$ verteporfin bolus over 1 minute, laser treatment after 5 minutes using $100 \mathrm{~J} / \mathrm{m}^{2}$ over $166 \mathrm{~s}$ ). ${ }^{62}$ All cases (100\%) showed clinical regression in treated lesions and there was no difference in BCVA between groups $(p=0.078){ }^{62}$ However, bolus VPDT was associated with RPE and retinal changes that were associated with reduced retinal sensitivity. ${ }^{62}$

Of the uncontrolled case series, the largest of these was a prospective, uncontrolled interventional case series investigating the use of VPDT (standard) in 31 patients with circumscribed choroidal hemangiomas conducted by Boixadera et al. (Table 4). ${ }^{63}$ After 12 months, cystoid macular edema had regressed in all cases and exudative macular detachment resolved in all but two cases, with most (82.8\%) patients requiring only one VPDT treatment to eliminate exudative retinal detachment. ${ }^{33}$ Mean VA increased from 20/60 at baseline to $20 / 35$ at 12 months ( $p<0.001$ ), with $69 \%$ of patients demonstrating visual recovery ( $p<0.001$ versus baseline)..$^{63}$ Choroidal hemangioma thickness decreased in all cases from a mean of $3.0 \mathrm{~mm}$ to $1.7 \mathrm{~mm}$ at 12 months, with the greatest effect seen after 4 weeks of treatment $(p<0.001$ versus baseline). ${ }^{63}$ No severe adverse events were reported. 
Table 3: Summary of key clinical trials involving VPDT for the treatment of PCV

\begin{tabular}{|c|c|c|c|c|c|c|}
\hline Study/author & $\begin{array}{l}\text { Patient } \\
\text { population }\end{array}$ & $\mathrm{n}$ & Study design & Treatment arms & Primary/key efficacy outcomes & Primary/key safety outcomes \\
\hline $\begin{array}{l}\text { EVEREST } \\
\text { Koh et al. } 2012^{50}\end{array}$ & $\begin{array}{l}\text { Asian adults with } \\
\text { symptomatic } \\
\text { macular PCV }\end{array}$ & 61 & $\begin{array}{l}\text { 6-month, } \\
\text { randomized, } \\
\text { double-masked, } \\
\text { multicenter }\end{array}$ & $\begin{array}{l}\text { - } \operatorname{VPDT}(\text { standard })+ \\
\text { RAN ( } 3 \times 0.5 \mathrm{mg}) \\
\text { - } \operatorname{VPDT}(\text { standard) } \\
\text { - } \text { RAN ( } 3 \times 05 \mathrm{mg})\end{array}$ & $\begin{array}{l}\text { VPDT + RAN vs VPDT vs RAN at } \\
6 \text { months } \\
\text { - } \text { Complete polyp regression: } \\
78 \% / 71 \% \text { vs } 29 \% ; \text {; }<0.01 \text { ) } \\
\text { - } \text { BCVA change: } 10.9 \text { (VPDT + RAN), } \\
7.5 \text { (VPDT), and } 9.2 \text { (RAN) letters }\end{array}$ & $\begin{array}{l}\text { - No new safety findings } \\
\text { with either treatment used } \\
\text { alone or in combination }\end{array}$ \\
\hline $\begin{array}{l}\text { EVEREST-II } \\
\text { Koh et al. } 2017^{48}\end{array}$ & $\begin{array}{l}\text { Asian adults with } \\
\text { symptomatic } \\
\text { macular PCV }\end{array}$ & 322 & $\begin{array}{l}\text { 24-month, } \\
\text { randomized, } \\
\text { double-masked, } \\
\text { multicenter }\end{array}$ & $\begin{array}{l}\text { - } \text { VPDT (standard) + } \\
\text { RAN (3 x } 0.5 \text { mg) } \\
\text { - } \text { RAN (3 x } 05 \text { mg) }\end{array}$ & $\begin{array}{l}\text { VPDT + RAN vs RAN at } 12 \text { months } \\
\text { - VA: + } 3.2 \text { letters treatment difference } \\
(95 \% \text { CI } 0.4-6.1) \text {, demonstrating } \\
\text { superiority of VPDT + RAN ( } p<0.001) \\
\text { - } \text { Polyp regression: } 69 \% \text { vs } 35 \% \\
(p<0.001)\end{array}$ & $\begin{array}{l}\text { (12-month data) } \\
\text { Vitreous hemorrhage (only } \\
\text { ocular serious adverse event) } \\
\text { - vPDT + RAN group: 1\%; } \\
\quad \text { RAN group: } 2 \%\end{array}$ \\
\hline $\begin{array}{l}\text { LAPTOP } \\
\text { Oishi et al. } \\
2013^{51} \\
\text { Oishi et al. } \\
2014^{52}\end{array}$ & $\begin{array}{l}\text { Treatment-naïve } \\
\text { PCV }\end{array}$ & 93 & $\begin{array}{l}\text { 24-month, } \\
\text { prospective, } \\
\text { randomized, } \\
\text { multicenter }\end{array}$ & $\begin{array}{l}\text { - vPDT (standard) } \\
\text { - } \text { RAN (3 x } 0.5 \text { mg) }\end{array}$ & $\begin{array}{l}\text { VPDT vs RAN at } 12 \text { months }{ }^{51} \\
\text { - Improved VA (0.2 LogMar): } 17 \% \text { vs } \\
30 \%(p=0.039) \\
\text { - VA: significantly greater in RAN } \\
\text { arm ( } p=0.011) \\
\text { VPDT vs RAN at } 24 \text { months }{ }^{52} \\
\text { - VA: significantly greater in RAN } \\
\text { arm ( } p=0.025)\end{array}$ & $\begin{array}{l}\text { (24-month data) } \\
\text { - Treatment switched to } \\
\text { RAN due to subretinal } \\
\text { hemorrhage or type } 2 \mathrm{CNV} \\
\text { in } 6 \% \text { of VPDT group } \\
\text { - Underwent vitrectomy due } \\
\text { to vitreous hemorrhage in } \\
2 \% \text { of VPDT group }\end{array}$ \\
\hline Lai et al. $2018^{53}$ & $\begin{array}{l}\text { Macular-involved } \\
\text { PCV }\end{array}$ & 57 & $\begin{array}{l}\text { 12-month, } \\
\text { prospective, } \\
\text { interventional, } \\
\text { single-center }\end{array}$ & $\begin{array}{l}\cdot 1+\text { PRN' VPDT } \\
\text { - } 1 \text { + PRN' RAN } \\
(0.5 \mathrm{mg}) \\
\cdot \text { VPDT + RAN } \\
\text { (0.5 mg) then PRN } \\
\text { RAN (0.5 mg) }\end{array}$ & $\begin{array}{l}\text { - LogMAR VA: significant } \\
\text { improvements in all treatment } \\
\text { groups vs baseline }(0.15-0.22 \text {; } \\
\text { p<0.05); no significant between- } \\
\text { group differences } \\
\text { - } \text { vPDT was superior to RAN } \\
\text { in achieving complete polyp } \\
\text { regression ( } 61 \% \text { vs } 22 \% ; p<0.05)\end{array}$ & $\begin{array}{l}\text { - } \text { Retinal hemorrhage in } 4 \% \\
\text { of VPDT and 6\% of VPDT + } \\
\text { RAN groups } \\
\text { - IOP elevation in 6\% of RAN } \\
\text { group } \\
\text { - } \text { No other serious ocular } \\
\text { AES }\end{array}$ \\
\hline $\begin{array}{l}\text { PLANET } \\
\text { Lee et al. } 2018^{54}\end{array}$ & $\begin{array}{l}\text { Predominantly } \\
\text { Asian adults } \\
\geq 50 \text { years with } \\
\text { symptomatic } \\
\text { macular PCV }\end{array}$ & 318 & $\begin{array}{l}\text { 96-week, } \\
\text { randomized, } \\
\text { double-masked, } \\
\text { multicenter, } \\
\text { sham-controlled }\end{array}$ & $\begin{array}{l}\text { - 'Rescue' vPDT + } \\
\text { aflibercept (2 mg) } \\
\text { - } \text { Sham PDT + } \\
\text { aflibercept (2 mg) }\end{array}$ & $\begin{array}{l}\text { - Aflibercept monotherapy was } \\
\text { non-inferior to combined 'rescue' } \\
\text { therapy for BCVA (+10.7 vs +10.8 } \\
\text { letters; } \mathrm{p}=0.55)\end{array}$ & $\begin{array}{l}\text { - Conjunctival hemorrhage } \\
\text { in } 5 \% \text { of sham PDT + } \\
\text { aflibecept group; dry eye } \\
\text { in } 6 \% \text { of 'rescue' vPDT + } \\
\text { aflibercept group } \\
\text { - Incidence of non-ocular } \\
\text { AEs between treatment } \\
\text { groups was similar }\end{array}$ \\
\hline
\end{tabular}

$A E=$ adverse event; $\mathrm{Cl}=$ confidence interval; $\mathrm{CNV}=$ choroidal neovascularization; EVEREST = efficacy and safety of verteporfin added to ranibizumab in the treatment of symptomatic macular polypoidal choroidal vasculopathy; IOP = intra-ocular pressure; LAPTOP= comparison of ranibizumab (Lucentis) and photodynamic therapy on polypoidal choroidal vasculopathy; $P C V$ = polypoidal choroidal vasculopathy; $P D T$ = photodynamic therapy; $P L A N E T$ = aflibercept in polypoidal choroidal vasculopathy; PRN = pro re nata (as required); RAN = ranibizumab; $V A=$ visual acuity; $V P D T=$ verteporfin photodynamic therapy.

With regard to modified VPDT protocols, Blasi et al. conducted a prospective, consecutive, uncontrolled, interventional case series investigating the use of VPDT (standard in 3/25 patients; double [100 $\mathrm{J} / \mathrm{cm}^{2}$ ] light dose in 22/25 patients) for the treatment of circumscribed choroidal hemangiomas (Table 4). ${ }^{64}$ The three eyes treated with standard VPDT received a second VPDT session with a $100 \mathrm{~J} / \mathrm{cm}^{2}$ light dose 1 month after the initial session. After 60 months' follow-up, mean VA had improved by 18.5 letters (Early Treatment Diabetic Retinopathy Study VA test; $p<0.001$ versus baseline), mean foveal thickness had decreased from $386.20 \mu \mathrm{m}$ to $179.2 \mu \mathrm{m}$, macular exudation was completely resolved in all cases, and all tumors were reduced in size. ${ }^{64}$ Similar to the findings of Boixadera et al., no treatment-related adverse events or complications were identified. ${ }^{64}$ In addition, although not a true choroidal disease, disc and retinal angiomatosis is also a clinical condition that has been reported to be successfully treated with VPDT.65,66

Overall, clinical evidence indicates that VPDT (both standard and double light doses) is an effective treatment for circumscribed choroidal hemangiomas, though radiation therapy may still be required for larger or more diffuse tumors with extensive exudative retinal detachment that are not suitable for VPDT therapy. ${ }^{2.59}$

\section{Peripapillary choroidal neovascularization}

Peripapillary CNV is usually idiopathic and is defined as CNV located within one disc diameter of the optic nerve head. ${ }^{2}$ Conventional treatment with laser photocoagulation has been associated with an increased risk 
Table 4: Summary of key clinical trials involving VPDT for the treatment of circumscribed choroidal hemangioma

\begin{tabular}{|c|c|c|c|c|c|c|}
\hline Study/author & Patient population & $\mathrm{n}$ & Study design & Treatment arms & Primary/key efficacy outcomes & $\begin{array}{l}\text { Primary/key safety } \\
\text { outcomes }\end{array}$ \\
\hline $\begin{array}{l}\text { Pilotto et al. } \\
2011^{62}\end{array}$ & $\begin{array}{l}\text { Symptomatic } \\
\text { circumscribed } \\
\text { choroidal } \\
\text { hemangioma }\end{array}$ & 20 & $\begin{array}{l}\text { Prospective, } \\
\text { randomized, case } \\
\text { series with a } \\
\text { mean follow-up of } \\
58 \text { months }\end{array}$ & $\begin{array}{l}\text { - } \text { vPDT (standard) } \\
\text { - } \text { Bolus vPDT } \\
\left(6 \mathrm{mg} / \mathrm{m}^{2}, 100 \mathrm{~J} /\right. \\
\left.\mathrm{m}^{2}, 166 \mathrm{~s}\right)\end{array}$ & $\begin{array}{l}\text { - All ( } 100 \%) \text { cases showed clinical regression } \\
\text { of treated lesions } \\
\text { - BCVA: No statistical difference between } \\
\text { groups ( } p=0.078 \text { ) }\end{array}$ & $\begin{array}{l}\text { Bolus VPDT associated } \\
\text { with RPE and retinal } \\
\text { changes leading to } \\
\text { reduced retinal sensitivity }\end{array}$ \\
\hline $\begin{array}{l}\text { Boixadera } \\
\text { et al. } 2009^{63}\end{array}$ & $\begin{array}{l}\text { Posterior pole } \\
\text { circumscribed } \\
\text { choroidal } \\
\text { hemangioma }\end{array}$ & 31 & $\begin{array}{l}\text { 12-month, } \\
\text { prospective, } \\
\text { non-randomized, } \\
\text { multicenter, case } \\
\text { series }\end{array}$ & VPDT (standard) & $\begin{array}{l}\text { 12-month data: } \\
\text { - Elimination of exudative retinal detachment: } \\
82.8 \% \text { (with one VPDT); } 13.8 \% \text { (two VPDTs); } \\
\text { 3.4\% (three vPDTs) } \\
\text { - VA: improved from 20/60 to 20/35 ( }<<0.001 \\
\text { vs baseline) } \\
\text { - Cystoid macular edema regressed in all cases }\end{array}$ & $\begin{array}{l}\text { No serious adverse events } \\
\text { were reported }\end{array}$ \\
\hline $\begin{array}{l}\text { Blasi et al. } \\
2010^{64}\end{array}$ & $\begin{array}{l}\text { Symptomatic } \\
\text { circumscribed } \\
\text { choroidal } \\
\text { hemangioma }\end{array}$ & 25 & $\begin{array}{l}\text { 5-year, prospective, } \\
\text { consecutive, } \\
\text { uncontrolled, case } \\
\text { series }\end{array}$ & $\begin{array}{l}\text { - } \operatorname{vPDT}(\text { standard; } \\
\mathrm{n}=3 \text { ) } \\
\text { - } \mathrm{VPDT}\left(100 \mathrm{~J} / \mathrm{m}^{2} ;\right. \\
\mathrm{n}=22)\end{array}$ & $\begin{array}{l}\text { 60-month data: } \\
\text { - Mean VA improved by } 18.5 \text { letters ( } p<0.001 \\
\text { vs baseline) } \\
\text { - Mean foveal thickness decreased from } \\
386.2 \mu \mathrm{m} \text { to } 179.2 \mu \mathrm{m}\end{array}$ & $\begin{array}{l}\text { No treatment-related AES } \\
\text { or complications were } \\
\text { identified }\end{array}$ \\
\hline
\end{tabular}

$A E=$ adverse events; $B C V A=$ best-corrected visual acuity; $R P E=$ retinal pigment epithelium; $V A=$ visual acuity; vPDT = verteporfin photodynamic therapy.

of thermal injury to the overlying neurosensory retina and visual loss. ${ }^{2}$ As such, VPDT could provide an effective alternative with a more favorable safety profile.

In line with this hypothesis, case series have shown that one or two treatments with VPDT can lead to regression of peripapillary CNV with only a small risk of adverse events (Table 1), ${ }^{67,68}$ whereas antiVEGF therapy may require multiple intravitreal injections to achieve regression..$^{69,70}$ In addition, while it has been advocated that the laser spot should not extend to within $200 \mu \mathrm{m}$ of the optic nerve in the treatment of CNV-associated $A M D,{ }^{2}$ there is some evidence that the optic head may be included in the VPDT treatment zone without causing optic nerve damage. ${ }^{68}$ Overall, vPDT provides an effective alternative to conventional photocoagulation therapy in peripapillary CNV with an improved safety profile, though further studies are warranted to confirm the findings and characterize the optimal VPDT protocol.

\section{Conclusion}

VPDT is a selective vaso-occlusive treatment that targets choroidal vascular abnormalities, which was initially used in ophthalmology to treat CNV associated with AMD. ${ }^{2}$ While anti-VEGF therapy has now replaced VPDT as the modality of choice for the treatment of AMD-associated CNV, clinical evidence indicates it is still an important treatment option for a range of choroidal conditions (either with or without anti-VEGF therapy), such as CSC, PCV, choroidal hemangioma and peripapillary CNV. In particular, VPDT used as an adjunct to anti-VEGF therapy can help to reduce the intravitreal injection burden and provide efficacy in patients with conditions refractive to anti-VEGF monotherapy, and numerous studies suggest that VPDT + anti-VEGF therapy may be the optimal treatment for patients with PCV. As such, further research is required to optimize the VPDT protocols for these conditions, varying aspects such as verteporfin dose and laser fluency to obtain the best balance between treatment efficacy and safety. $\square$
1. Dougherty TJ, Gomer CJ, Henderson BW, et al. Photodynamic therapy. J Natl Cancer Inst. 1998;90:889-905.

2. Newman DK. Photodynamic therapy: current role in the treatment of chorioretinal conditions. Eye (Lond). 2016;30:202-10.

3. Miller JW, Schmidt-Erfurth U, Sickenberg M, et al. Photodynamic therapy with verteporfin for choroidal neovascularization caused by age-related macular degeneration: results of a single treatment in a phase 1 and 2 study. Arch Ophthalmol 1999;117:1161-73.

4. Schmidt-Erfurth U, Miller JW, Sickenberg M, et al. Photodynamic therapy with verteporfin for choroidal neovascularization caused by age-related macular degeneration: results of retreatments in a phase 1 and 2 study. Arch Ophthalmol. 1999;117:1177-87.

5. VISUDYNE (verteporfin for injection) summary of product characteristics. Available at: https://www.accessdata.fda.gov/ drugsatfda_docs/label/2012/021119s022lbl.pdf (accessed November 14, 2019).

6. Miller JW, Walsh AW, Kramer M, et al. Photodynamic therapy of experimental choroidal neovascularization using lipoproteindelivered benzoporphyrin. Arch Ophthalmol. 1995;113:810-8.

. Schmidt-Erfurth U, Hasan T. Mechanisms of action of photodynamic therapy with verteporfin for the treatment of agerelated macular degeneration. Surv Ophthalmol. 2000;45:195-214.

8. Bressler NM. Treatment of Age-Related Macular Degeneration with Photodynamic Therapy Study G, Photodynamic therapy of subfoveal choroidal neovascularization in age-related macular degeneration with verteporfin: two-year results of 2 randomized clinical trials-tap report 2. Arch Ophthalmol. 2001;119:198-207. 9. Verteporfin In Photodynamic Therapy Study Group. Verteporfin therapy of subfoveal choroidal neovascularization in age-related macular degeneration: two-year results of a randomized clinical trial including lesions with occult with no classic choroidal neovascularization-verteporfin in photodynamic therapy report 2 Am J Ophthalmol. 2001:131:541-60.

10. Photodynamic therapy of subfoveal choroidal neovascularization in age-related macular degeneration with verteporfin: one-year results of 2 randomized clinical trials-TAP report. Treatment of age-related macular degeneration with photodynamic therapy (TAP) Study Group. Arch Ophthalmol. 1999;117:1329-45.

11. VISUDYNE ${ }^{\circledast}$ (verteporfin for injection) prescribing information. Available at: https://www.accessdata.fda.gov/drugsatfda_docs/ label/2016/021119s027lbl.pdf (accessed November 14, 2019).

12. Chan WM, Lim TH, Pece A, et al. Verteporfin PDT for non-standard indications-a review of current literature. Graefes Arch Clin Exp Ophthalmol. 2010;248:613-26.

13. Lang GE, Mennel S, Spital G, et al. [Different indications of photodynamic therapy in ophthalmology Klin Monbl Augenheilkd. 2009;226:725-39.

14. Mennel S, Barbazetto I, Meyer $\mathrm{CH}$, et al. Ocular photodynamic therapy — standard applications and new indications (part 1). Review of the literature and personal experience. Ophthalmologica. 2007;221:216-26.

15. Mennel S, Barbazetto I, Meyer $\mathrm{CH}$, et al. Ocular photodynamic therapy — standard applications and new indications. Part 2. Review of the literature and personal experience. Ophthalmologica. 2007;221:282-91.

16. Bakri SJ, Thorne JE, Ho AC, et al. Safety and efficacy of antivascular endothelial growth factor therapies for neovascular agerelated macular degeneration: a report by the American Academy of Ophthalmology. Ophthalmology. 2019;126:55-63.

17. Amoaku WM, Chakravarthy U, Gale R, et al. Defining response to anti-VEGF therapies in neovascular AMD. Eye (Lond). 2015;29:721-31.

18. Soubrane G, Bressler NM. Treatment of subfoveal choroidal neovascularisation in age related macular degeneration: focus on clinical application of verteporfin photodynamic therapy. $\mathrm{Br}$ J Ophthalmol. 2001;85:483-95.

19. Bird AC, Bressler NM, Bressler SB, et al. An international classification and grading system for age-related maculopathy and age-related macular degeneration. The International ARM Epidemiological Study Group. Surv Ophthalmol. 1995;39:367-74.

20. Green WR, Enger C. Age-related macular degeneration histopathologic studies. The 1992 Lorenz E. Zimmerman Lecture. Ophthalmology. 1993;100:1519-35.

21. US Department of Health and Human Services National Institutes of Health, Age-related macular degeneration. Available at: https://archives.nih.gov/asites/report/09-09-2019/report.nih. gov/nihfactsheets/ViewFactSheet8aac. html?csid=69\&key=A\#A (accessed 27 November, 2019)

22. US National Institutes of Health (NIH), Age-Related Eye Disease 
Study (AREDS), 2019. Available at: https://uww.nei.nih.gov/ research/clinical-trials/age-related-eye-disease-study-areds (accessed November 27, 2019).

23. Brown DM, Kaiser PK, Michels M, et al. Ranibizumab versus verteporfin for neovascular age-related macular degeneration. N Eng/ J Med. 2006:355:1432-44.

24. Brown DM, Michels M, Kaiser PK, et al. Ranibizumab versus verteporfin photodynamic therapy for neovascular age-related macular degeneration: Two-year results of the ANCHOR study. Ophthalmology. 2009;116:57-65.

25. Rosenfeld PJ, Brown DM, Heier JS, et al. Ranibizumab for neovascular age-related macular degeneration. $N$ Eng/ I Med. 2006;355:1419-31.

26. Kaiser PK, Boyer DS, Cruess AF, et al. Verteporfin plus ranibizumab for choroidal neovascularization in age-related macular degeneration: twelve-month results of the DENALI study. Ophthalmology. 2012;119:1001-10

27. Larsen M, Schmidt-Erfurth U, Lanzetta P, et al. Verteporfin plus ranibizumab for choroidal neovascularization in age-related macular degeneration: twelve-month MONT BLANC study results. Ophthalmology. 2012;119:992-1000

28. Gallemore RP, Wallsh J, Hudson $\mathrm{HL}$, et al. Combination verteporfin photodynamic therapy ranibizumab-dexamethasone in choroida neovascularization due to age-related macular degeneration: results of a phase II randomized trial. Clin Ophthalmol. 2017;11:223-31.

29. Wolf S, Balciuniene VJ, Laganovska G, et al. RADIANCE: a randomized controlled study of ranibizumab in patients with choroidal neovascularization secondary to pathologic myopia. Ophthalmology. 2014:121:682-92.

30. Kang HM, Koh HJ. Intravitreal anti-vascular endothelial growth factor therapy versus photodynamic therapy for idiopathic choroidal neovascularization. Am J Ophthalmol. 2013;155:713-9.

31. Heier JS, Brown D, Ciulla T, et al. Ranibizumab for choroidal neovascularization secondary to causes other than age-related macular degeneration: a phase I clinical trial. Ophthalmology. 2011;118:111-8.

32. Gallemore E, Nguyen D. Review of Ophthalmology. When anti-VEGF treatment fails. 2008. Available at: $h t t p s: / / w w w$. reviewofophthalmology.com/article/when-anti-vegf-treatmentfails (accessed November 14, 2019).

33. Nicholson B, Noble J, Forooghian F, et al. Central serous chorioretinopathy: update on pathophysiology and treatment. Surv Ophthalmol. 2013;58:103-26.

34. Kitzmann AS, Pulido JS, Diehl NN, et al. The incidence of central serous chorioretinopathy in Olmsted County, Minnesota, 1980-2002. Ophthalmology. 2008:115:169-73.

35. Quin G, Liew G, Ho IV, et al. Diagnosis and interventions for central serous chorioretinopathy: review and update. Clin Exp Ophthalmol. 2013;41:187-200.

36. Chan WM, Lai TY, Lai RY, et al. Half-dose verteporfin photodynamic therapy for acute central serous chorioretinopathy: one-year results of a randomized controlled trial. Ophthalmology. 2008;115:1756-65.

37. Bae SH, Heo J, Kim C, et al. Low-fluence photodynamic therapy versus ranibizumab for chronic central serous chorioretinopathy: one-year results of a randomized trial. Ophthalmology. 2014;121:558-65.

38. Asahi MG, Chon AT, Gallemore $E$, et al. Photodynamic therapy combined with antivascular endothelial growth factor treatment for recalcitrant chronic central serous chorioretinopathy. Clin Ophthalmol. 2017;11:2051-6.

39. Reibaldi M, Cardascia N, Longo A, et al. Standard-fluence versus low-fluence photodynamic therapy in chronic central serous chorioretinopathy: a nonrandomized clinical trial. Am J Ophthalmol. 2010:149:307-15.

40. Wu ZH, Lai RY, Yip YW, et al. Improvement in multifocal electroretinography after half-dose verteporfin photodynamic therapy for central serous chorioretinopathy: a randomized placebo-controlled trial. Retina. 2011;31:1378-86.

41. Semeraro F, Romano MR, Danzi P, et al. Intravitreal bevacizumab versus low-fluence photodynamic therapy for treatment of chronic central serous chorioretinopathy. Jpn J Ophthalmol. 2012;56:608-12

42. Russo A, Turano R, Morescalchi F, et al. Comparison of half-dose photodynamic therapy and $689 \mathrm{~nm}$ laser treatment in eyes with chronic central serous chorioretinopathy. Graefes Arch Clin Exp Ophthalmol. 2017:255:1141-8.

43. Cheng $\mathrm{CK}$, Chang $\mathrm{CK}$, Peng $\mathrm{CH}$. Comparison of photodynamic therapy using half-dose of verteporfin or half-fluence of laser light for the treatment of chronic central serous chorioretinopathy. Retina. 2017;37:325-33.

44. Ma J, Meng N, Xu X, et al. System review and meta-analysis on photodynamic therapy in central serous chorioretinopathy. Acta Ophthalmol. 2014;92:e594-601.

45. Lu HQ, Wang EQ, Zhang T, et al. Photodynamic therapy and anti-vascular endothelial growth factor for acute central serous chorioretinopathy: a systematic review and meta-analysis. Eye (Lond). 2016;30:15-22.

46. Erikitola OC, Crosby-Nwaobi R, Lotery AJ, et al. Photodynamic therapy for central serous chorioretinopathy. Eye (Lond). 2014;28:944-57.

47. QLT Inc., Qlt receives orphan drug designation for Visudyne for treatment of central serous chorioretinopathy. Press release available at: https://www.sec.gov/Archives/edgar/ data/827809/000119312512120593/d318066dex991.htm (accessed November 14, 2019)

48. Koh A, Lai TYY, Takahashi K, et al. Efficacy and safety of ranibizumab with or without verteporfin photodynamic therapy. for polypoidal choroidal vasculopathy: a randomized clinical trial. JAMA Ophthalmol. 2017;135:1206-13.

49. Yang S, Zhao J, Sun X. Resistance to anti-VEGF therapy in neovascular age-related macular degeneration: a comprehensive review. Drug Des Devel Ther. 2016;10:1857-67.

50. Koh A, Lee WK, Chen $\sqcup$, et al. EVEREST study: efficacy and safety of verteporfin photodynamic therapy in combination with ranibizumab or alone versus ranibizumab monotherapy in patients with symptomatic macular polypoidal choroidal vasculopathy. Retina. 2012;32:1453-64.

51. Oishi $\mathrm{A}$, Kojima $\mathrm{H}$, Mandai $\mathrm{M}$, et al. Comparison of the effect of ranibizumab and verteporfin for polypoidal choroidal vasculopathy: 12-month LAPTOP study results. Am J Ophthalmol. 2013;156:644-51.

52. Oishi A, Miyamoto N, Mandai M, et al. LAPTOP study: a 24-month trial of verteporfin versus ranibizumab for polypoidal choroidal vasculopathy. Ophthalmology. 2014:121:1151-2.

53. Lai K, Li Y, Zhou L, et al. Comparison of the effects of photodynamic therapy, intravitreal ranibizumab and combination for polypoidal choroidal vasculopathy under $1+$ PRN regimen. BMC Ophthalmol. 2018;18:144

54. Lee WK, lida T, Ogura Y, et al. Efficacy and safety of intravitreal aflibercept for polypoidal choroidal vasculopathy in the PLANET study: a randomized clinical trial. JAMA Ophthalmo 2018;136:786-93.

55. Wong CW, Cheung CM, Mathur R, et al. Three-year results of polypoidal choroidal vasculopathy treated with photodynamic therapy: retrospective study and systematic review. Retina. 2015;35:1577-93.

56. Wang $\mathrm{W}$, He M, Zhang $\mathrm{X}$. Combined intravitreal antiVEGF and photodynamic therapy versus photodynamic monotherapy for polypoidal choroidal vasculopathy: a systematic review and meta-analysis of comparative studies. PLOS One. 2014;9:e110667

57. Koh $A H$, Expert PCVP, Chen $L$, et al. Polypoidal choroidal vasculopathy: evidence-based guidelines for clinical diagnosis and treatment. Retina. 2013;33:686-716

58. Wong TY, Ogura Y, Lee WK, et al. Efficacy and safety of intravitreal aflibercept for polypoidal choroidal vasculopathy: two-year results of the Aflibercept in Polypoidal Choroidal Vasculopathy Study. Am J Ophthalmol. 2019;204:80-9.

59. Frau E, Rumen F, Noel G, et al. Low-dose proton beam therapy for circumscribed choroidal hemangiomas. Arch Ophthalmol. 2004;122:1471-5.

60. Tsipursky MS, Golchet PR, Jampol LM. Photodynamic therapy of choroidal hemangioma in sturge-weber syndrome, with a review of treatments for diffuse and circumscribed choroidal hemangiomas. Surv Ophthalmol. 2011;56:68-85.

61. Zhang Y, Liu W, Fang Y, et al. Photodynamic therapy for symptomatic circumscribed macular choroidal hemangioma in Chinese patients. Am J Ophthalmol. 2010;150:710-5

62. Pilotto $E$, Urban F, Parrozzani $R$, et al. Standard versus bolus photodynamic therapy in circumscribed choroida hemangioma: functional outcomes. Eur $J$ Ophthalmol. 2011;21:452-8

63. Boixadera A, Garcia-Arumi J, Martinez-Castillo V, et al. Prospective clinical trial evaluating the efficacy of photodynamic therapy for symptomatic circumscribed choroidal hemangioma. Ophthalmology. 2009;116:100-5.

64. Blasi MA, Tiberti AC, Scupola A, et al. Photodynamic therapy with verteporfin for symptomatic circumscribed choroidal hemangioma: five-year outcomes. Ophthalmology. 2010;117:1630-7.

65. American Acadamey of Ophthalmology, Retinal Angiomatosis, 2019. Available at: https://www.aao.org/bcscsnippetdetail. aspx?id=bcb19a18-a218-46ed-8b7f-902b8d1bc385 (accessed November 14, 2019)

66. Atebara NH, Retinal capillary hemangioma treated with verteporfin photodynamic therapy. Am I Ophthalmol. 2002:134:788-90.

67. Rosenblatt BJ, Shah GK, Blinder K. Photodynamic therapy with verteporfin for peripapillary choroidal neovascularization. Retina. 2005;25:33-7.

68. Bernstein PS, Horn RS. Verteporfin photodynamic therapy involving the optic nerve for peripapillary choroidal neovascularization. Retina. 2008:28:81-4.

69. Figueroa MS, Noval S, Contreras I. Treatment of peripapillary choroidal neovascular membranes with intravitreal bevacizumab. Br J Ophthalmol. 2008;92:1244-7.

70. Hoeh $A E$, Schaal $K B, A c h T$, et al. Treatment of peripapillary choroidal neovascularization with intravitreal bevacizumab. Eur J Ophthalmol. 2009;19:163-5. 